\title{
Relationship Between Organizational Climate And Self-Concept With Effectiveness Of Interpersonal Communication
}

\author{
'Aria Nur Farida Muslicha, ${ }^{2}$ Nurbianta, ${ }^{3 S}$ ri Endang Herudiati \\ 1,2,3Sekolah Tinggi IImu Tarbiyah Muhammadiyah Tanjung Redeb, Berau, Kalimantan Timur \\ I*arialovina@gmail.com, 2lta_bianta@ymail.com, 3sriherudiati@gmail.com
}

\begin{tabular}{l}
\hline Info \\
\hline Article history \\
Accepted November 30, 2021 \\
Revised January 23, 2022 \\
Accepted January 30 \\
\hline
\end{tabular}

Keywords: Organizational Climate, Selft-Concept, Effectiveness of Interpersonal Communication

\begin{abstract}
The research was conducted to determine whether there is a significant relationship between Organizational Climate and Self-Concept with the Effectiveness of Interpersonal Communication at the Sekolah Tinggi IImu Tarbiyah Muhammadiyah Tanjung Redeb either partially or simultaneously. This study was designed using a correlational quantitative approach through survey methods. The target population was all 45 educators and education staff at the Sekolah Tinggi IImu Tarbiyah Muhammadiyah Tanjung Redeb. The number of research samples is 30 teaching staff. Samples were purposive random sampling. This study indicates a significant relationship between organizational climate (X1) and the effectiveness of head interpersonal communication $(Y)$ with the percentage contribution of variable $\mathrm{X} 1$ to $\mathrm{Y}$ of $40 \%$. Then there is a significant relationship between Self-Concept (X2) and the Effectiveness of Head Interpersonal Communication $(Y)$ with a correlation coefficient of ry2 $=0.628$. The results then show that there is a significant relationship between Organizational Climate (X1) and Self-Concept (X2) with the Effectiveness of Leader Interpersonal Communication (Y) with a correlation coefficient of ry $12=0.707$ and the coefficient of determination $\mathrm{r} 2 \mathrm{y} 12=0.262$ significant at 0.05 . This shows that $50 \%$ of the leaders' interpersonal communication is determined jointly by organizational climate and self-concept. Base on the research finding indicated a good atmosphere related to the organizational climate provides comfort for each individual to build a positive self-concept, and this is related to the effectiveness interpersonal communication of institutional leader. Where, there were never found in the previous researches the combination among organizational climate and self-concept, influence the effectiveness of Interpersonal communication simultaneously.
\end{abstract}

\section{INTRODUCTION}

Communication in education management plays a very important role in achieving educational goals. In the framework of implementing communication, the leader has a very decisive role. He should always provide motivation, encouragement, and an invitation to always give the best for his educational institution. Communication that is carried out intensively and continuously will have strong implications for lecturers employees, and also students to always try to be the best.

Communication is sharing information, thoughts and feelings between people through speaking, writing or body language (Braithwaite \& Schrodt, 2021; Solomon et al., 2021; Mukhtar et al., 2020). To achieve effective communication, a concept is a material sent and 
understood by others. The goals of effective communication include creating general perceptions, changing behavior and obtaining information (Mukhtar et al., 2020; Okoro et al., 2017). In the school organization environment, communication is an essential activity (McNatt, 2020). Husaini Usman (2011) states, two or more people need communication between them in working together. The better their communication, the better their chances of working together. Effective communication requires mutual respect, trust, openness and responsibility. Therefore, head interpersonal communication is critical in creating an effective managerial atmosphere. Trenholm and Jansen in Suranto Aw (2011) state that interpersonal communication as communication between two people takes place face to face (dyadic communication). The nature of this communication is: (a) spontaneous and informal; (b) receive maximum mutual feedback; (c) participants play a flexible role. In the same vein as conveyed by Indry Irianti, communication within an organization is the main thing in achieving organizational goals. Liliwerj (2011) emphasized, interpersonal communication is communication between individuals. It is strengthened by Hardjana (2006), interpersonal communication is a face-to-face interaction between two or several people, where the sender can convey the message directly, and the message recipient can receive and respond directly as well. In the other words, interpersonal communication is face-to-face interaction, between communicators who are the senders of messages to the communicants as recipients of messages in verbal and non-verbal forms.

As coveyed by Masturawaty Mustafa (2021), one type of communication that has a high frequency of occurrence is interpersonal communication. Interpersonal communication has the potential to carry out an instrumental function as a tool to influence or persuade others, because we can use our five sensory tools to enhance the persuasion of the messages we communicate to our communicants. As the most complete and perfect communication, interpersonal communication plays an important role at any time, as long as humans still have emotions. Likewise Azmirul, Masyhuri, M.Psi.(2013) conclude elements of organizational climate is readiness technology to improve employee work methods, establish good interpersonal communication.

To create communication effectiveness, organizational climate is a part that also needs attention. Andrew W. Halpin and Don B. Croff in Hoy et al. (2005) developed the Organizational Climate Description Questionaire (OCDQ-RE), which describes licture behaviour and leader behaviour, each of which consisting of three dimensions. The six dimensions of organizational climate are supportive leader behaviour, directive leader behaviour, restrictive leader behaviour (restrictive behaviour), collegial lecturer behaviour (collegial behaviour), intimate lecturer behaviour (intimate behaviour), and disengaged lecturer. Behaviour (tenuous behaviour). These dimensions form the types of work climates, open, engaged, disengaged, and closed. 
Meanwhile, Halpin and Crof in Wirawan, 2007; Mahendra \& Suwandana, 2020; Siregar \& Evanita, 2020 have identified a continuum on organizational climate and based on the results of their research using the Organizational Climate Description Questionnaire (OCDQ-RE). OCDQ-RE further classifies organizational climate into four types as listed in the table with the following descriptions; 1) An open organizational climate (open climate), namely the organizational climate of cooperation and mutual respect among lecturers, and between lecturers and school leaders; 2) Climate opposite (engaged climate), which is an organizational climate characterized by ineffective efforts by the leader to control lecturers and on the other hand the professional performance of the lecturers; 3) The climate is mutually supportive (disengaged climate), which contrasts to the engaged climate. The leader is open and attentive and supportive; 4) Close organizational climate, an organizational climate that is antithetical to an open organizational climate.

Another thing that is related to the effectiveness of interpersonal communication is selfconcept. According to William D. Brooks in Jalaluddin Rakhmat (2003) the self-concept defines self-concept as "those physical, social, and psychological perceptions of ourselves that we have derived from experiences and our interactions with others". So, self-concept is our view and our feelings about ourselves. This perception of self can be physical, psychological, and social.

As for questions that raise self-perception, for example, how do I behave? (Psychological perception), how do other people see me? (Social perception), how do I view my appearance? (Physical perception). Self-concept is not just a descriptive picture, but also your assessment of yourself. That way, the self-concept includes what you feel and what you think and feel about yourself. Similar was stated by Anita Taylor et al. in Jaladdin Rakhmat (2003) self-concept is defined as "all you think and feel about you, the entire complex of beliefs, and attitudes you hold about yourself".

Thus, there are two components of self-concept: a cognitive component and an affective component. It could be that your cognitive component is, "I'm a smart person," and your affective component says, "I like being smart; this is better for me." It may be that then cognitive component is like that, but the affective component says, "I am very embarrassed because I am an intelligent person." In social psychology, the cognitive component is called self-image, and the affective component is called self-esteem. Both, according to William D. Brooks and Philip Emmert (1976), will have a major influence on interpersonal communication patterns. Meanwhile, Colhoun and Acocella in Berry (1993), explain that the self-concept aspect includes several dimensions; 1) The dimension of knowledge is about what is known about oneself. Such as physical form, age, citizenship, hobbies and so on .; 2) The dimension of hope, a self-view of the possibilities that occur in the future. Hope can be said to be an ideal self. With the hope of generating the driving force to achieve these hopes in the future; 3 ) The assessment dimension, is an assessment that involves elements of evaluation, how individuals 
like themselves and their dislikes themselves. The assessment dimension is a significant component of self-concept formation.

On the other hand, based on the results of pre-observation, the researcher found that there was still a gap between leaders and lecturers. Leaders who are less commutation are difficult to provide support to lecturers to create an institutional atmosphere where the organizational climate is conducive, open and lecturers who do not have strong self-concept tend to be reluctant to accept suggestions from the leadership. This has an impact on the leadership's interpersonal communication running less effectively.

Based on the description above, this research will attempt to examine, "The Relationship between Organizational Climate and Self-Concept with Effectiveness Of Interpersonal Communication". To meet the research objectives, the study would focus to measurement of the elements of interpersonal communication effectiveness whose dimensions include: openness, empathy, supportive attitudes, positive attitudes, and equality. Which is formed through manipulation of organizational climate and positive self-concept.

\section{METHODS}

In this study using quantitative research methods, according to Sugiyono (2013) it can be interpreted as a research method based on the philosophy of positivism, used to research on certain populations or samples, The target population was all 45 educators and education staff at the Sekolah Tinggi IImu Tarbiyah Muhammadiyah Tanjung Redeb. The number of research samples is 30 teaching staff. Samples were purposive random sampling. Data was collected using a questionnaire, it tested using Likert scale. The variables of this study are organizational climate (X1) and self-concept (X2) accompanied by one dependent variable, namely the effectiveness of the leader's interpersonal communication (Y). And the three research variables are connected. The pattern of this relationship is: (1) the relationship between variables $X 1$ and $Y,(2)$ the relationship between variables $X 2$ and $Y,(3)$ the relationship between variables $X 1$ and $X 2$ together with variable $Y$, these three patterns of relationships are tested to determine the relationship between variables and is illustrated in the following picture:

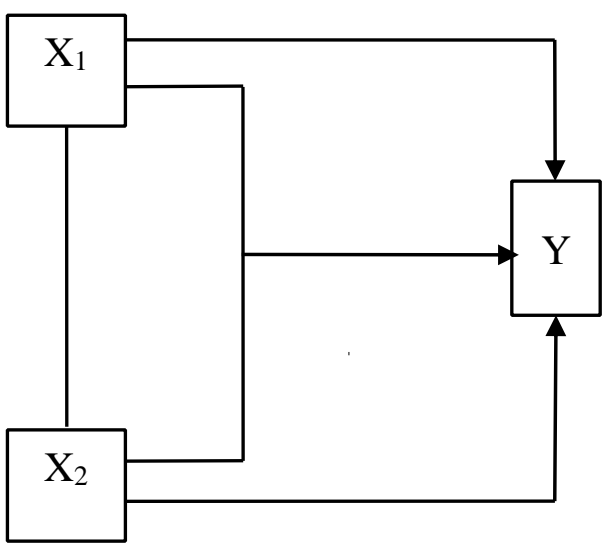

Remarks :

$\mathrm{X} 1$ : Climate Organization Variables..

X2 : Selft-Concept Variables. $Y$ : Effectiveness of Interpersonal Communication variables. 
Figure 1: Research Constellation

Data analysis started from validity testing using product moment correlation, reliability testing using alpha cronbach, normality testing using Kolmogorov-Smirnov and homogeneity testing. The main analysis was partial correlation, regression analysis used ANOVA, and demonstrate hypothesis using $t$ test.

\section{RESULTS AND DISCUSSION}

This section is to explain the research findings and interpretations as follows:

\subsection{The Relationship between Organizational Climate $(X 1)$ and Leader's Interpersonal Communication Effectiveness $(Y)$.}

The study findings indicate a significant relationship between organizational climate and the effectiveness of interpersonal communication; this contribution can be indicated by a determination value of $40 \%$, which is directly significant. This means that a conducive organizational climate, this situation significantly affects the effectiveness of interpersonal communication. This means that it is believed that organizational climate will increase the effectiveness of interpersonal communication because each individual can create a conducive organizational climate and create synergy so that the effectiveness of interpersonal communication is significantly carried out well.

Tabel 1. ANOVA Significance Test and Regression Linearity $\hat{Y}=53,154+1,0461 \times 1$

\begin{tabular}{llllll}
\multicolumn{1}{l}{ ANOVA } & df & SS & MS & F & Significance $F$ \\
\hline Regression & 1 & 820035.3 & 820035 & 3265 & $1.04945 \mathrm{E}-29$ \\
Residual & 28 & 7031.684 & 251.132 & & \\
Total & 29 & 827067 & & & \\
a. & Predictors : (constant) Organization Climate \\
b. Dependent Variabel : Effectiveness Of Interpersonal Communication
\end{tabular}

From the values listed in the ANOVA table above for the simple regression test, it is obtained that Fcount $=3265$ with $\mathrm{db}$ for the numerator is 1 and $\mathrm{db}$ for the denominator is 28 , having a value greater than Ftable $=4.20$ while for a significance level of $1 \%, F$ table $=7.64$. Thus from this condition it can be concluded that the direction and regression coefficients are significant or very meaningful.

The strength of the relationship between variable $X 1$ and variable $Y$ is stated by the regression equation $\hat{Y}=53,154+1,0461 \times 1$. This regression shows that every one-point increase in the organizational climate score (X1) will be followed by an increase in the leader's interpersonal communication effectiveness score $(Y)$ by 1.0461 points at a constant of 53.154 . If controlling for the other predictor variables, namely controlling for the self-concept variable $(\mathrm{X} 2)$, then the partial correlation coefficient between $\mathrm{X} 1$ and $Y$ is 0.3967 . Furthermore, the t-test is carried out to determine the significance level of the relationship between $\mathrm{X} 1$ and $\mathrm{Y}$. Thus it 
can be concluded that the regression equation $\mathrm{Y}$ over $\mathrm{X} 1$ is called linear. It can be described in the following graph:

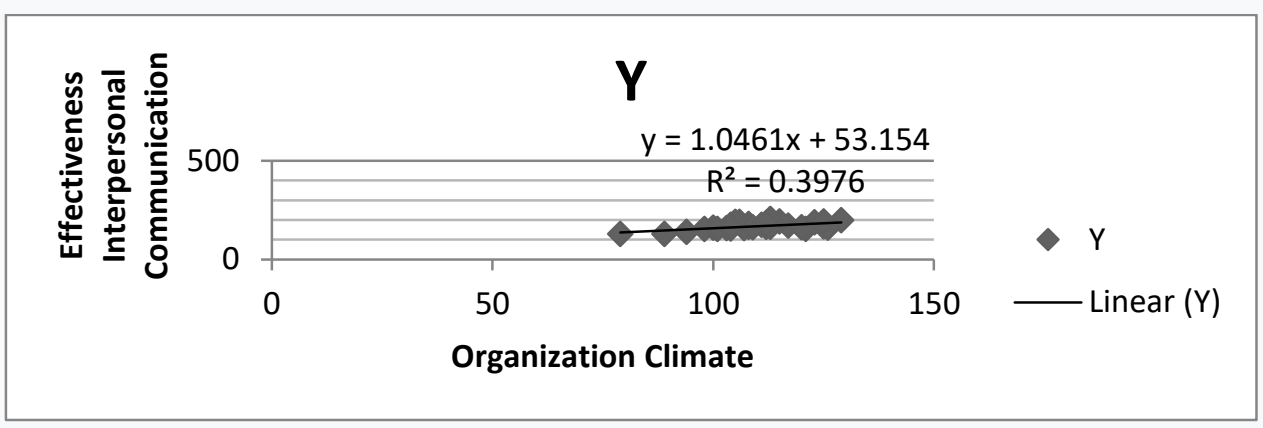

Figure 2 Regression Line Equation Relationship Between Organizational Climate (X1) and Interpersonal Communication Effectiveness $(Y)$

Based on the results of the above calculations, it is obtained that tcount of 5.289 is greater than $t$ table of 2.467 with $\mathrm{db}=28$ at the real level $\mathrm{a}=0.05$, so it can be concluded that by controlling $X 2$ the relationship between $X 1$ and $Y$ remains significant. This study's findings have succeeded in accepting Ho, who stated; "There is a significant relationship between Organizational Climate and the Effectiveness of Leader Interpersonal Communication".

Based on testing this hypothesis, it can be stated that the organizational climate variable has a strong relationship with the effectiveness of interpersonal communication. Likewise the opinion of Sri Wahyunie ; Sanggar Kanto2 ; Rachmat Kriyantono3, (2015) that communication climate organization has a positive and significant effct on interpersonal communication effectiveness. That is, the high and low organizational climate is believed to have a positive impact on the effectiveness of interpersonal communication as indicated by the increased support among each personnel working together in implementing the program, in carrying out teaching tasks properly, an open climate atmosphere will show that the interaction between individuals is well established, this will impact on the effectiveness of interpersonal communication.

\subsection{The Relationship between Self-Concept (X2) and the Effectiveness of the Leader's Interpersonal Communication $(\mathrm{Y})$.}

In the second hypothesis data processing, it is concluded that there is a significant relationship between self-concept and the effectiveness of interpersonal communication, by a determination value of $39 . \%$ can show the directly significant contribution. This means that a positive self-concept of the lecturer will make it easier for him to communicate. This situation has a significant relationship with the effectiveness of interpersonal communication.

Tabel 2. ANOVA Significance Test and Regression Linearity $\hat{Y}=61.286+0.9856 \times 2$

\begin{tabular}{llllll} 
ANOVA & & & & & \\
\hline & & & & & Significance \\
& $d f$ & $S S$ & MS & $F$ & $F$ \\
\hline Regression & 1 & 819507 & 819507 & 3035 & $2.79158 \mathrm{E}-29$ \\
Residual & 28 & 7559.85 & 269.99 & & \\
Total & 29 & 827067 & & & \\
\hline
\end{tabular}




\section{c. Predictors : (constant) Selft-Concept \\ d. Dependent Variabel : Effectiveness Of Interpersonal Communication}

From the values listed in the ANOVA table above for the simple regression test, it is obtained that Fcount $=3035$ with $\mathrm{db}$ for the numerator is 1 and $\mathrm{db}$ for the denominator is 28 , having a value greater than Ftable $=4.20$ while for a significance level of $1 \%, F$ table $=7.64$. Thus from this condition it can be concluded that the direction and regression coefficients are significant or very meaningful.

The strength of the relationship between variable $X 2$ and variable $Y$ is expressed by the regression equation $\hat{Y}=61.286+0.9856 X 2$ This regression shows that an increase will follow every one-point increase in the interpersonal communication effectiveness score ( $Y$ ) by 0.9856 points at a constant of 61.286 If controlling for other predictors variables, namely control of the organizational climate variable (X1), then the partial correlation coefficient between $X 2$ and $Y$ is 0.3948 . Furthermore, the t-test is carried out to determine the significance level of the relationship between $X 2$ and $Y$. Thus it can be concluded that the regression equation $Y$ over $\mathrm{X} 2$ is called linear. It can It can be described in the following graph:

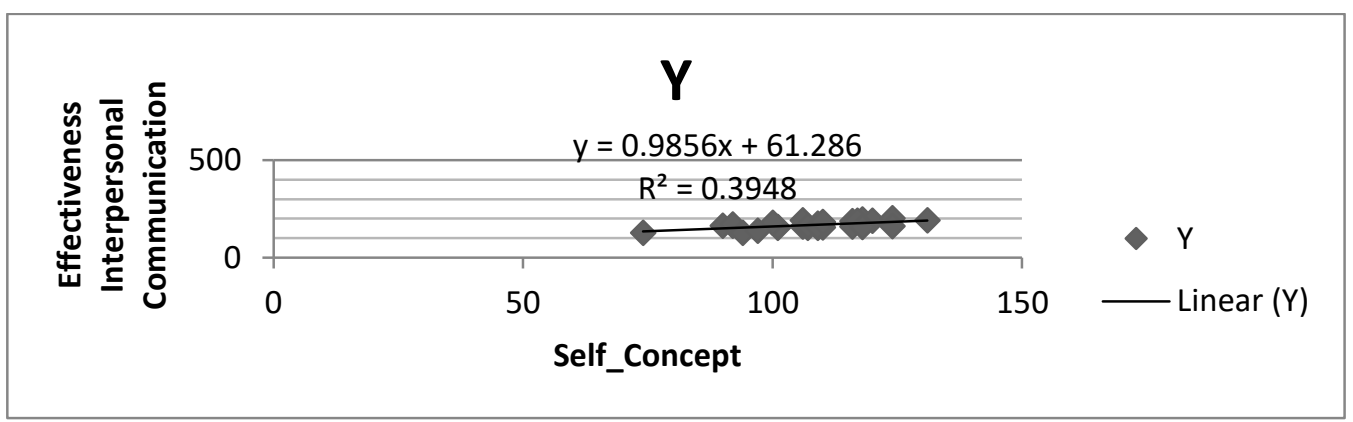

Figure 3 Regression Line Equation Relationship Between Self-Concept (X2) and Principal's Interpersonal Communication Effectiviness $(Y)$

Based on the hypothesis testing, it can be stated that the self-concept variable has a strong relationship with the effectiveness of interpersonal communication. In line with what was stated by Safitri Yulikhah.1 Baidi Bukhori,2 Ali Murtadho,3 (2019) and Prabbakararao Sampthirao (2016), the results of this study supported previous research and showed how self concept had an influence on interpersonal communicatrion for infividuals that is, high and low self-concept is believed to have a positive impact on the effectiveness of interpersonal communication, indicated by the ability to receive information, being able to accept 
suggestions and criticism patiently, thinking positively to the other person, making it easier to convey problems in the work environment in a formal or informal setting.

\subsection{The relationship between organizational climate (X1) and self-concept (X2) together with the effectiveness of the leader's interpersonal communication $(Y)$.}

Tabel 3. ANOVA Significance Test and Regression Linearity $\hat{Y}=2.764+0.670 \times 1+0.611 \times 2$.

\begin{tabular}{llllll} 
ANOVA & & & & & \\
\hline & $d f$ & SS & MS & $F$ & $\begin{array}{l}\text { Significance } \\
\text { Regression }\end{array}$ \\
2 & 821619.9 & 410809.9 & 2036.274 & $2.69441 \mathrm{E}-29$ \\
Residual & 27 & 5447.139 & 201.7459 & & \\
Total & 29 & 827067 & & & \\
\hline
\end{tabular}

Based on the calculation that the variable (X1) and (X2) with the variable (Y) obtained a double correlation of 0.707 . From the results of hypothesis testing, it is obtained that Fcount of 2036 is greater than F-table 3.35 with $\mathrm{db}$ of the numerator $=2, \mathrm{db}$ of the denominator $=27$ and the real level of $a=0.05$, so it can be seen that there is a significant relationship between organizational climate and self-concept together. - the same in determining the effectiveness of interpersonal communication. The strength of the relationship between two independent variables and one dependent variable is expressed by the multiple regression equation $\hat{Y}=$ $2.764+0.670 \times 1+0.611 \times 2$.

From the coefficient of determination between organizational climate (X1) and selfconcept $(\mathrm{X} 2)$ together with the effectiveness of interpersonal communication $(Y)$ is $(0.707) 2=$ 0.500, meaning that organizational climate and self-concept contribute to the effectiveness of interpersonal communication by $50 \%$. In comparison, the rest is determined by other factors. Thus the variance in interpersonal communication effectiveness can be explained by the organizational climate variable (X1) and self-concept (X2) through the regression equation $\hat{Y}$ $=2.764+0.670 \times 1+0.611 \times 2$.

Based on the calculation of the null hypothesis $(\mathrm{Ho})$ which states that "There is a significant relationship between organizational climate and self-concept with the effectiveness of interpersonal communication", accepted. In line with Irwan (2017); Juliana, K., Erdiansyah,r. (2020), dan Pujiati, T. \& Triadi, R. B. (2016), self-cocept is one of the determining factors in one's interpersonal communication. Thus, testing this hypothesis can state that the organizational climate and self-concept variables have a strong relationship with interpersonal communication effectiveness. These results can be explained that, if the organizational climate is felt to be open and conducive to school members and the self-concept of lecturers who can receive and review information well, and can to implement it and change the lecturer's attitude to be better than before, it shows that the effectiveness of interpersonal communication has Well done. Conversely, the more closed and unstable the organizational 
climate felt by school members, and the lecturer self-concepts, it is possible that the effectiveness of interpersonal communication will not be achieved.

\section{CONCLUSION}

Based on the implementation of research and the results of data processing trough data interpretation of each variable and the dimensions of these variables, it can be concluded as follows:; 1) An organizational climate that supports each other between superiors and subordinates will make it easier for superiors and subordinates to make it easier for personnel to interact through communication. This will certainly support the effectiveness of interpersonal communication; 2) A positive lecturer's self-concept will make it easier for him to communicate. And the effectiveness of interpersonal communication will have a positive impact on self-concept. In line with Qolbi, Ade Ifroh (2013), and Azrimul. \& Masyuri (2015) who stated that if interpersonal communication is implemented properly it can provide a good organizational climate as well. This shows that there is a relationship between interpersonal communication and organizational climate; 3) The perceived organizational climate is an open organizational climate, a self-concept that positively support of interpersonal communication effectiveness. From the above explanation, it can be concluded that an open organizational climate and positive self-concept can increase the effectiveness of interpersonal communication. In line with Indri Irianti (2016), communication in an organization is the main thing in achieving organizational goals.

\section{REFERENCE}

Azrimul, Masyhuri, M.Psi. Hubungan Antara Komunikasi Interpersonal Dengan Iklim Organisasi Pada Pegawai SMA Negeri 1 XIII Koto Kampar Kabupaten Kampar-Riau. Menara, Vol. 12 No. 1 Januari - Juni 2013. https://media.neliti.com/media/publications/220451hubungan-antara-komunikasi-interpersonal.pd

Azrimul. \& Masyuri. (2015) Komunikasi Interpersonal ditinjau dari iklim organisasi. Jurnal Psikologi. 11 (1), 1-4. http://dx.doi.org/10.24014/jp.v11i1.1552

Berry, L.M. and Houston.(1993). Psychology at Work. USA: WCB Brown \& Benchmark.

Braithwaite, D. O., \& Schrodt, P. (2021). Engaging theories in interpersonal communication: Multiple perspectives. books.google.com. https://books.google.com/books?hl=en\&lr=\&id=CdhCEAAAQBAJ\&oi=fnd \&pg=PT8\&da =interpersonal+communication\&ots=L_y $\mathrm{VOnXQzg \& sig=NKcgHT-}$ xiaxpGPOBUbWjDO2Bbj0

Hardjana, Andre. (2000), Audit Komunikasi Teori dan Pratek, Jakarta: PT Grasindo.

Hoy, W. K. \& Miskel, C. G. (2005). Education Administration Theory, Research and Practice. $7^{\text {th }}$ edition. New Mork: McGraw-Hill. Retrieved from https://digitalcommons.unl.edu/cgi/viewcontent.cgi? article=1452\&context=libphilprac 
Husnaini, Usman. (2011). MANAJEMEN, Teori, Pratik, dan Riset Pendidikan. Jakarta: Bumi Aksara. Indry Irianti, HUBUNGAN EFEKTIVITAS KOMUNIKASI DAN IKLIM ORGANISASI DENGAN KEPUASAN KERJA KARYAWAN PT. BANK TABUNGAN NEGARA KANTOR CABANG X. Repository Esa Unggul. https://digilib.esaunggul.ac.id/hubungan-efektivitas-komunikasi-dan-iklimorganisasi-dengan-kepuasan-kerja-karyawan-pt-bank-tabungan-negara-kantorcabang-x-8083.html

Irwan, S. (2017). Pengaruh konsep diri terhadap komunikasi interpersonal mahasiswa. Scholaria: Jurnal Pendidikan dan Kebudayaan, 7(1), 39-48. https://doi.org/10.24246/i.scholaria.2017.v7.i1.p39-48

Juliana, K., Erdiansyah, R. (2020). Pengaruh konsep diri dan self disclosure terhadap Komunikasi interpersonal mahasiswa. Koneksi, 4(1), 29-35. http://dx.doi.org/10.24912/kn.v4i1.6

Liliweri, Alo. (2011). KOMUNIKASI Serba Ada Serba Makna. Jakarta: Kencana.

Mahendra, I. M. P., \& Suwandana, I. G. M. (2020). Job Satisfaction as a Mediating Variable Climate Organization to Influenced Turnover Intention. ajhssr.com. https://www.ajhssr.com/wp-content/uploads/2020/07/J20475359.pdf

Masturawaty Mustafa, THE EFFECT OF EMPLOYEE INTERPERSONAL COMMUNICATION EFFECTIVINESS ON THE ORGANIZATIONAL CLIMATE AT COMMUNICATION THE STATE POLYTECHNIC UJUNG PANDANG, KAREBA Journal Komunikasi Vol 10 No. 1 Januari - Juni 2021 file:///C:/Users/ACER/Downloads/15252-Article\%20Text-50605-1-1020210818\%20(1).pdf

McNatt, D. B. (2020). Service-learning: An experiment to increase interpersonal communication confidence and competence. Education+ Training. https://doi.org/10.1 108/ET-02-2019-0039

Mukhtar, M., Risnita, R., \& ... (2020). The Influence of Transformational Leadership, Interpersonal Communication, and Organizational Conflict On Organizational Effectiveness. International Journal Of .... https://ejournal.unib.ac.id/index.php/IJER/article/view/10371

Okoro, E., Washington, M. C., \& Thomas, O. (2017). The impact of interpersonal communication skills on organizational effectiveness and social self-efficacy: A synthesis. In International Journal of Language .... ijllnet.com. http://www.ijllnet.com/journals/Vol_4_No_3_September_2017/3.pdf

Prabbakararao Sampthirao, Self-Concept and Interpersonal Communication, The international Journal Of Indian Psychology 3 (3) June 2016. https://www.researchgate.net/publication/347096925 Self_Concept_and_Interpersonal Communication

Pujiati, T. \& Triadi, R. B. (2016). Pengaruh Konsep Diri dan Budaya Dalam Komunikasi Interpersonal. Prosiding Seminar Nasional UU ITE VS Budaya Komunikasi di Indonesia. 1 (1). http://openjournal.unpam.ac.id/index.php/Proceedings/article/view/1185 
Qolbi, Ade Ifroh. (2013). Hubungan Antara Komunikasi Interpersonal dengan Iklim Organisasi di SDN 034 Samarinda, Jurnal IImu Komunikasi Universitas Mulawarman. 1 (1): 22- 3 https://scholar.google.com/scholar?hl=en\&as sdt=0\%2C $5 \& q=i k l i m+o r g a n i s a s i+p a d a+k$ omunikasi+interpersonal\&btnG=\#d=gs aabs\&u=\%23p\%3DiDxydeTD3MUJ

Rakhmat, Jalaluddin. (2012). PSIKOLOGI KOMUNIKASI. Bandung: PT REMAJA ROSDAKARYA.

Safitri Yulikhah,1 Baidi Bukhori,2 Ali Murtadho3, Self concept, self efficacy, and interpersonal communication effectiveness of student. Psikohumaniora: Jurnal Penelitian Psikologi, Vol 4, No 1 (2019): 65-76 DOI: http://dx.doi.org/10.21580/pjpp.v4i1.3196

Siregar, F. L. S., \& Evanita, S. (2020). The Effect of Transformational Leadership, Organization Climate and Work Discipline on Employee Performance at Royal Denai Group Hotel Bukittinggi. In 4th Padang International Conference on .... atlantis-press.com. https://www.atlantis-press.com/article/125935768.pdf

Solomon, D. H., Brinberg, M., Bodie, G. D., \& ... (2021). A dynamic dyadic systems approach to interpersonal communication. ... of Communication. https://academic.oup.com/joc/article-abstract/71/6/1001/6375398

Sri Wahyunie 1 ; Sanggar Kanto2 ; Rachmat Kriyantono3 Pengaruh Iklim Komunikasi Organisasi Terhadap Efektivitas Komunikasi Interpersonal Dan Kepuasan Kerja (Studi Eksplanatif di Dinas Kebudayaan, Pariwisata, Pemuda dan Olah Raga Kabupaten Gunung Mas Kalimantan Tengah). Wacana Vol. 18, No. 2 (2015). https://media.neliti.com/media/publications/163360-ID-pengaruh-iklim-komunikasiorganisasi-ter.pdf

Sugiyono.(2012). MetodePenelitianPendidikan.Bandung :Alfabeta Suranto Aw.(2011). Komunikasi Interpersonal.Yogyakarta :Grahallmu

Wirawan, (2007), Budaya dan Iklim Organisasi :Teori Aplikasi dan Penelitian, Jakarta : Salemba Empat. 